\title{
PENGARUH KETERBUKAAN INFORMASI PUBLIK TERHADAP PEMBANGUNAN DESA DI KANTOR DESA PINANG KECAMATAN CENDANA KABUPATEN ENREKANG
}

\author{
1)Nurhikmah Aryani JR, ${ }^{2}$ Muh. Arisal Asad \\ Fakultas IImu Sosial dan IImu Politik Universitas Muhammadiyah Sidenreng Rappang \\ nurhikmaharyani@gmail.com
}

\begin{abstract}
Abstrak
Populasi dalam penelitian ini berjumlah 305 masyarakat desa Pinang dengan jumlah sampel sebanyak 75 orang yang didasarkan pada penentuan sampel menggunakan rumus Slovin. Tipe penelitian yang digunakan dalam penelitian ini tipe assosiatif yang bertujuan untuk mengetahui pengaruh atau hubungan antara dua variabel atau lebih yaitu keterbukaan informasi public terhadap pembangunan desa. Karena penelitian ini akan menggambarkan fakta-fakta dan menjelaskan keadaan dari objek penelitian berdasarkan $f$ mengharapkan untuk memutuskan dampak atau hubungan antara setidaknya dua faktor, khususnya pengungkapan data terbuka pada perbaikan kota. Karena penelitian ini akan menggambarkan realitas saat ini dan memperjelas kondisi objek eksplorasi yang bergantung pada realitas saat ini sebagaimana adanya dan mencoba untuk menyelidiki untuk memberikan realitas yang bergantung pada informasi yang diperoleh di lapangan. Hasil menunjukkan bahwa ada dampak kritis antara akta-fakta sebagaimana adanya dan mencoba menganalisis untuk memberi kebenarannya berdasarkan data yang diperoleh di lapangan. Hasil penelitian menunjukkan bahwa terdapat pengaruh yang signifikan antara keterbukaan informasi publik terhadap pembangunan desa Pinang Kecamatan Cendana Kabupaten Enrekang. Kontribusi atau determinasi yang diberikan oleh variabel keterbukaan informasi publik terhadap pembangunan desa adalah $D=(0,815)^{2} \times 100 \%=66 \%$. Artinya variabel keterbukaan informasi public memberikan kontribusi sebesar $66 \%$ terhadap pembangunan desa Pinang, sedangkan sisanya $44 \%$ dipengaruhi oleh variabel lain yang tidak diikutkan dalam penelitian.
\end{abstract}

Kata kunci: keterbukaan informasi publik, pembangunan desa

\begin{abstract}
The type of research used in this study is associative type which aims to determine the effect or relationship between two or more variables. The type of research used in this research is descriptive quantitative research. Because this research will describe the facts and explain the state of the object of research based on the facts as they are and try to analyze to give the truth based on the data obtained in the field. The population in this study amounted to 305 people in Pinang village with a sample of 75 people based on the determination of the sample using the Slovin formula. Data collection techniques used observations, questionnaires, literature studies and interviews. The results of the study indicate that there is a significant influence between public information disclosure on the development of Pinang village, Cendana District, Enrekang Regency. The contribution or determination given by the variable of public information disclosure to village development is $D=(0.815) 2 x 100 \%=66 \%$. This means that the variable of public information disclosure contributes $66 \%$ to the development of Pinang village, while the remaining $44 \%$ is influenced by other variables not included in the study.
\end{abstract}

Keywords: public information disclosure, village development

JIA | Volume 9 | Nomor 2 | Edisi Agustus 2021 


\section{A. PENDAHULUAN}

Indonesia sebagai negara agraris terus melakukan lompatan-lompatan ke depan yang berbeda untuk menemukan negaranegara maju. Salah satu cara yang dilakukan oleh otoritas publik adalah dengan mendukung percepatan peningkatan kemajuan di daerah dengan menerapkan aturan swasembada daerah. Mengingat Undang-Undang Nomor 23 Tahun 2014 tentang Otonomi Daerah bahwa setiap daerah diberi kedudukan dan kewajiban untuk mengkoordinasikan kepentingan daerahnya tergantung pada pedoman pengungkapan data publik.

Kota berasal dari bahasa Sansekerta, yang berarti negara, negara, atau asal. Kota tidak terlepas dari kehidupan agraris dan keterusterangan. Menurut Kamus Besar Bahasa Indonesia, kota adalah kesatuan wilayah yang dimiliki oleh berbagai keluarga yang mempunyai susunan pemerintahan sendiri (dipimpin oleh seorang kepala kota) atau kota adalah kumpulan rumah-rumah di luar kota yang merupakan satu kesatuan. kemampuan daerah setempat untuk mencapai batas keuangan yang berkembang dan setara.

Undang-Undang Nomor 6 Tahun 2014 tentang Penyelenggaraan Pemerintahan Kota dimaksudkan untuk mempertegas keadaan kota sebagai suatu lembaga pemerintahan dan diandalkan untuk menunjukkan wilayah setempat dan memungkinkan jaringan kota. Dengan undang-undang ini, pemerintah memberikan pendekatan dalam pengembangan Alokasi Dana Desa (ADD) sebagai bentuk desentralisasi moneter untuk berubah menjadi kota otonom. Dengan adanya Peraturan Pemerintah Republik Indonesia Nomor 47 Tahun 2015 tentang Perubahan Atas Undang-undang Tidak Resmi Nomor 43 Tahun 2014 tentang Pelaksanaan Pedoman Undang-Undang Nomor 6 Tahun 2014 tentang Kekotaan.

Permen Desa PDTT 17 Tahun 2019 tentang Pedoman Umum Pembangunan dan Pemberdayaan Masyarakat Desa diberikan untuk melaksanakan pembangunan kota yang partisipatif dan wajar serta untuk mensinergikan pergantian peristiwa dan penguatan jaringan negara dengan program pemerintah dan pemerintah lingkungan, penting untuk menumbuhkan aturan di kota perbaikan yang sesuai dengan kebutuhan daerah kota.

ADD sebagaimana dimaksud dalam Peraturan Pemerintah Republik Indonesia pasal 1 angka 47 Tahun 2015 adalah cadangan penyesuaian yang diperoleh daerah/kota dalam pendapatan provinsi daerah/kota dan rencana pengeluaran setelah dikurangi 3 Dana Alokasi Khusus. Pemanfaatan ADD memerlukan penataan, pelaksanaan, pengawasan, dan tanggung jawab pemanfaatannya.

Pemanfaatan ADD cenderung pada kegiatan palsu yang dilakukan oleh pihakpihak yang tidak bertanggung jawab atas penyelenggaraan ADD. Penting untuk menggarap pameran pemerintah kota dan Badan Pengawas Desa, daerah juga diperlukan dalam mengelola pemanfaatan rencana keuangan yang diperoleh dari pemerintah pusat, mulai dari penyusunan, pelaksanaan, pengorganisasian, perincian dan tanggung jawab. tahapan sesuai pedoman yang relevan. Sehingga pelaksanaan perbaikan kota dapat berjalan dengan baik. Kota-kota dalam menjalankan posisi, hak dan komitmennya dalam menghadapi kapasitas terpendamnya perlu dilakukan secara lugas.

Keterlibatan

pengelolaan pembangunan desa harus sesuai dengan Undang-Undang yang berlaku pada pembangunan desa. Pembangunan desa yang dimaksud adalah pembangunan nonfisik. Pembangunan non fisik merupakan jenis pembangunnan yg tercipta oleh dorongan masyarakat setempat dan memiliki jangka waktu yang lama. Strategi pembangunan non fisik yang terlalu sentralistik merupakan contoh ketidak pastian birokrasi terhadap variasi pembangunan masyarakat lokal dan kurang tanggap terhadap kepentingan serta kebutuhan akan masyarakat ditingkat Desa. Hal ini menyebabkan partisipasi dan spirit masyarakat untuk mengembangkan potensi lokal tidak dapat berkembang dengan wajar.

Dijelaskan dalam Bab 2 Pasal 2 tentang standar administrasi moneter provinsi dalam Peraturan Menteri Dalam Negeri Nomor 20 Tahun 2018, dana kota diawasi dengan prinsip lugas, bertanggung jawab, partisipatif dan dilakukan dalam disiplin pembelanjaan yang efisien. Penerimaan memastikan akses bagi masyarakat umum untuk mendapatkan data tentang 
administrasi, khususnya data tentang strategi, metode yang terlibat dalam pembuatan dan pelaksanaannya, serta hasil yang dicapai. Dengan demikian, selama ini transparansi tidak hanya dimanfaatkan oleh otoritas publik tetapi juga publik yang juga memiliki pilihan untuk memperoleh data yang mengidentifikasikan dengan kepentingan publik, sehingga pendekatan masyarakat umum ikut serta dalam interaksi yang dinamis.

Penerimaan mengandung arti bahwa dalam menjalankan kewenangan publik, otoritas publik terkadang mengungkapkan hal-hal materiil kepada pihak-pihak yang berkepentingan, untuk situasi ini wilayah lokal yang lebih luas sehingga aturan transparansi memungkinkan masyarakat pada umumnya untuk mengetahui dan memperoleh akses ke data sebanyak-banyaknya. tentang dana teritorial. Penerimaan memastikan akses atau kesempatan bagi setiap orang untuk memperoleh data tentang organisasi pemerintah, menjadi data spesifik tentang strategi, metode yang terlibat dalam pembuatan dan pelaksanaannya, serta hasil yang dicapai.

Mengingat Undang-Undang Nomor 6 Tahun 2014 tentang Desa, Desa berkewajiban membantu program perbaikan non-aktual yang bersifat umum, lumrah, dan kebutuhan daerah/kota sesuai dengan kewenangannya. Salah satu latihan kemajuan non-aktual yang ada di Kantor Desa Pinang, Kecamatan Cendana, Kabupaten Enrekang adalah penghindaran yang menghalangi, kota perlu membina proyek/latihan signifikan yang disubsidi oleh Dana Desa.

Peneliti memilih Kantor Dessa Pinang Kecamatan Cendana Kabupaten Enrekang sebagai objek penelitian krna desa tersebut merupakann satu satunya desa. diiKabupaten Enrekang ygdipilih sbgai lokasi khusus untuk melaksanakan program pencegahan stuntng. Berdasarkan hasil pengamatan dan wawancara dengan salah satu tokoh masyarakat, diketahui adanya aduan masyarakat yang protes terhadap ketidaksesuaian salah satu program pembangunan desa non fisik desa sebagai hasil musrembang. Pembangunan desa non fisik yang dimaksud adalah program stunting, program stunting menjadi prioritas di Desa Pinang Kecamatan Cendana Kabupaten Enrekang. Namun, program stunting ini membuat masyarakat resah karena tidak sesuai dengan hasil musrembang. Dimana diketahui oleh masyarakat, bahwa dana yang disediakaan untuk program stunting tidak sesuai dengan realisasi yang dilakukan, Realisasi anggaran untuk program stunting hanya pemberian obat, vitamin, dan makanan yang bergizi yang terealisasi. Sehingga membuat program ini tidak tepat sasaran. Dengan adanya keterbukaann informasi public menjamin akses bagi setiap masyarakat untuk memperoleh informasi dan berpartisipasi mengontrol setiap langkah daan kebijakn yang diambil pemerintah sehinga penyelenggaraan pemerintah dapat dipertanggung jawabkan kepada masyarakat.

Berdasarkan masalah di atas, maka calon peneliti tertarik untuk mengetahui dan meneliti lebih dalam tentang "Pengaruh Keterbukaan Informasi Publik Terhadap Pembangunan Desa di Kantor Desa Pinang Kecamatan Cendana Kabupaten Enrekang".

\section{B. METODDE PENELITIAN}

Tipe penelitian yg digunakan dalam penelitiain tipe assosiatif. Menurut Sugiyono (2016: 4) tipe assosiatif rencana untuk memutuskan dampak atau hubungan antara setidaknya dua faktor. Eksplorasi ini dilakukan dengan hipotesis bahwa kemampuan untuk memperjelas, mengantisipasi dan mengendalikan suatu indikasi.

Sugiyono (2016:20) mengatakan bahwa jenis eksplorasi yang digunakan dalam penelitian ini adalah jenis pemeriksaan ilustratif kuantitatif. Karena penelitian ini akan menggambarkan realitas saat ini dan memperjelas kondisi objek penelitian berdasarkan realitas saat ini sebagaimana adanya dan berusaha untuk memberikan realitas berdasarkan informasi yang diperoleh di lapangan tentang dampak paparan data publik terhadap kemajuan kota di kota. Kantor Desa Pinang, Kecamatan Cendana, Kabupaten Enrekang.

Berdasarkan data dari Kantor Desa Pinang Kecamatan Cendana Kabupaten Enrekang Tahun 2020, populasi dalam penelitian ini berjumlah 305. Berdasarkan perhitungan rumus di atas, maka sampel penelitian berjumlah 75 orang. Penyelidikan informasi dalam eksplorasi kuantitatif adalah suatu pergerakan setelah informasi dari semua responden atau sumber informasi 
yang berbeda dikumpulkan. Latihan dalam investigasi informasi adalah memperkenalkan informasi untuk setiap faktor yang dipertimbangkan, melakukan estimasi untuk menjawab definisi masalah (Sugiyono, 2016: 147). Informasi yang telah dikumpulkan dilakukan dengan pemeriksaan langsung kekambuhan dengan bantuan program SPSS 20.0 for windows.

\section{HASIL DAN PEMBAHASAN}

Aparatur desa memberikan informasi kepada semua pihak yang membutuhkan (stakeholders) secara jelas dan akurat. Berdasarkan hasil penelitian maka didapatkan hasil kuesioner untuk pertanyaan seputar pemberian informasi oleh aparatur Desa Pinang kepada semua pihak yang membutuhkan secara jelas dan akurat diperoleh skor total sebesar $86 \%$ sehingga dapat dikategorikan berjalan dengan baik. Aparatur desa Pinang memberikan kesempatan kepada seluruh stakeholders untuk memperoleh informasi seputar pembangunan desa Pinang secara jelas dan akurat, layanan keterbukaan informasi pembangunan disampaikan kepada masyarakat melalui pertemuan-pertemuan yang rutin dilakukan antara aparatur desa dengan masyarakat pada kantor Desa.

Pemberian layanan informasi pembangunan desa secara mudah kepada masyarakat hasil penelitian maka didapatkan hasil kuesioner untuk pertanyaan seputar Pemberian layanan informasi pembangunan desa secara mudah kepada masyarakat desa Pinang diperoleh skor total sebesar $87 \%$ sehingga dapat dikategorikan berjalan dengan baik. Berdasarkan temuan dilapangan diketaui bahwa masyarakat mendapatkan layanan informasi pembangunan desa secara mudah. Masyarakat dapat menanyakan langsung kepada kepala Desa mengenai pembangunan desa maupun melalui kepala dusun di tiap-tiap dusun yang ada di desa Pinang.

Seluruh stakeholders dapat mengakses informasi publik dengan mudah, hasil penelitian maka didapatkan hasil kuesioner untuk pertanyaan seputar stakeholders dapat mengakses informasi public dengan mudah diperoleh skor total sebesar $87 \%$ sehingga dapat dikategorikan berjalan dengan baik. Temuan dalam penelitian menunjukkan bahwa seluruh pihak yang berkepentingan dapat dengan mudah mengakses informasi public di Desa Pinang. Akses informasi dapat dilakukan dengan berkunjung langsung di kantor desa untuk menanyakan hal seputar pembangunan desa.

Jaminan keterbukaan informasi public kepada masyarakat, hasil kuesioner untuk pertanyaan seputar jaminan keterbukaan informasi publik diperoleh skor total sebesar $84 \%$ sehingga dapat dikategorikan berjalan dengan baik. Aparatur desa Pinang berkomitmen untuk senantiasa menjamin adanya keterbukaan informasi public yang ada di Desa Pinang sehingga sinergi antara aparatur desa dan masyarakat dapat terjaga yang diharapkan memberikan dampak positif untuk pembangunan desa.

Pengaduan masyarakat apabila tidak terjadi keterbukaan informasi publik di Desa Pinang, hasil kuesioner untuk pertanyaan seputar pengaduan yang dapat dilakukan masyarakat apabila tidak terjadi keterbukaan informasi publik di Desa Pinang diperoleh skor total sebesar $88 \%$ sehingga dapat dikategorikan berjalan dengan baik. Temuan dalam penelitian menunjukkan bahwa kepala desa Pinang menjamin keterbukaan informasi public kepada masyarakat, kepala desa Pinang berkomitmen bahwa apabila terdapat aparatur desa yang tidak memberikan akses keterbukaan informasi public kepada masyarakat maka masyarakat dapat melapor langsung ke kepala desa ataupun pada kantor kecamatan hingga Inspektorat Kabupaten Enrekang.

Pembangunan pada desa Pinang sesuai dengan kebutuhan masyarakat, hasil kuesioner untuk pertanyaan seputar Pembangunan pada desa Pinang sesuai dengan kebutuhan masyarakat diperoleh skor total sebesar $85 \%$ sehingga dapat dikategorikan berjalan dengan baik. Pembangunan yang dilaksanakan pada desa Pinang merupakan hasil dari musyawarah antara aparatur desa dan masyarakat desa pada saat Musrenbang sehingga pembangunan yang dilaksanakan merupakan pembangunan yang sesuai dengan kebutuhan masyarakat.

Partisipasi masyarakat dalam pembangunan desa Pinang, maka didapatkan hasil kuesioner untuk pertanyaan seputar partisipasi masyarakat dalam pembangunan desa Pinang diperoleh skor total sebesar $88 \%$ sehingga dapat dikategorikan berjalan dengan baik. 
Masyarakat desa Pinang senantiasa dilibatkan dalam proses pembangunan baik pada tahap perencanaan hingga pelaksanaan. Keterlibatan masyarakat dala perencanaan pembangunan dapat dilihat pada saat Musrenbang Desa dilakukan masyarakat diundang untuk hadir menyampaikan aspirasi pembangunan desa.

$$
\text { Pembangunan Desa Pinang }
$$

mencerminkan kepentingan dan kebutuhan semua pihak, Berdasarkan hasil penelitian maka didapatkan hasil kuesioner untuk pertanyaan seputar Pembangunan Desa Pinang mencerminkan kepentingan dan kebutuhan semua pihak diperoleh skor total sebesar $86 \%$ sehingga dapat dikategorikan berjalan dengan baik. Pembangunan yang dilaksanakan pada desa Pinang adalah pembangunan yang telah disepakati bersama masyarakat pada saat Musrenbang desa dilaksanakan. Sehingga pembangunan yang dilaksanakan telah mencermintan kebutuhhan semua pihak.

Pembangunan yang dilakukan di desa Pinang melengkapi pembangunan yang sudah ada sebelumnya, diperoleh skor total sebesar $86 \%$ sehingga dapat dikategorikan berjalan dengan baik. Pembangunan yang dilaksanakan pada desa Pinang merupakan pembangunan yang berkelanjutan dimana pembangunan tersebut dari period eke periode secara konsisten.

Pembangunan desa Pinang mengacu pada peraturan yang berlaku diperoleh skor total sebesar $86 \%$ sehingga dapat dikategorikan berjalan dengan baik. Pembangunan di desa Pinang telah disesuaikan peraturan yang berlaku sehingga dapat disimpulkan bahwa perencanaan hingga pelaksanaan pembangunan desa Pinang dilaksanakan berdasarkan peraturan yang berlaku.

Kontribusi atau determinasi yang diberikan oleh variabel keterbukaan informasi publik terhadap pembangunan desa adalah $\mathrm{D}$ $=(0,815)^{2} \times \quad 100 \%=66 \%$. Artinya variabel keterbukaan informasi public memberikan kontribusi sebesar $66 \%$ terhadap pembangunan desa Pinang, sedangkan sisanya $44 \%$ dipengarruhioleh variabel lain yang tidak diikutkan dalam penelitian.

Hal ini menunjukkan bahwa sebesar $66 \%$ pembanguann desa Pinang dipengaruhi oleh variabel independen yaitu keterbukaan informasi publik. Sedangkan sisanya sebesr
44\% dipengaruhiolehvariabel-variabel lainnya yang tidaditeliti.

Koefisien regresi pembangunan desa Pinang jika tanpa adanya nilai variabel keterbukaan informasi publik $(X=0)$, maka tingkat pembangunan desa berada pada nilai 4,453. Jika keterbukaan informasi publik (X) bertambah maka diprediksi pembangunan desa Pinang akan meningkat sebesar 0.794.

Berdasarkanhasil SPSS. makaSig= $00.000<\alpha=0.05$ sehinggaHoditolak danHa ditterima sehinga dinyatakn bahwatrdapat pengruh yg signifikan antra keterbukaan informasi publik trhdap pembangunan desa Pinang Kecamatan Cendana Kabupaten Enrekang.

Berdasarkan tabbel annova sehingga diperoleh nilai dari $F_{\text {hitung }}=144,085$ sedangkan menggunakan tabel distribusi $F$ diperoleh nilai $F_{\text {tabel }}=3.97$ yang berarti $F_{\text {hitung }}$ $>F_{\text {tabel }}$ makaHoditolak daHa ditrima, artinya terdapatpengaruhyansignifikanantara

keterbukaan informasi publik trhadp pembangunan desa Pinang Kecamatan Cendana Kabupaten Enrekang.

\section{KESIMPULAN}

Mengingat hasil eksplorasi yang telah digambarkan di bagian sebelumnya, sangat baik dapat disimpulkan bahwa:

1. Dilihat dari uji $t$ dan $u j i ~ f$ cenderung beralasan bahwa terdapat pengaruh kritis antara keterbukaan informasi publik terhadap pembangunan desa Pinang Kecamatan Cendana Kabupaten Enrekang.

2. Kontribusi atau determinasi yang diberikan oleh variabel keterbukaan informasi publik terhadap pembangunan desa adalah $D=(0,815)^{2} \times 100 \%=66 \%$. Artinya variabel keterbukaan informasi public memberikan kontribusi sebesar $66 \%$ terhadap pembangunan desa Pinang, sedangkan sisanya $44 \%$ dipengaruhi oleh variabel lain yang tidak diikutkan dalam penelitian.

\section{E. REFERENSI}

Adisasmita, Rahadjo. 2013. Pembangunan Pedesaan. Yogyakarta: Graha IImu.

\section{Ahmad,J.2015.MetodePenelitian Administrasi Publik:Teori.danAplikasi.Yogyakarta: Gava Media.}

Erani, Ahmad Yustika. 2015. Sistem 
PembangunaDesa.Jakarta:.Kementeri anDesaPembangunan.Daerah TertinggaldanTransmigrasiRepublik Indonesia.

Hanif, Nurcholis. 2011. Pertumbuhan \& Penyelenggaraan Pemerintahan Desa. Jakarta: Erlangga.

Kurniawan,Borni.2015.DesaMandiriDesa Membangun.Jakarta:Kementrian Desa,PembangunanDaerah. TertinggaldanTransmigrasiRepublik Indonesia.

Miraza,B.H,dkk.2010.Pembangunan Pedesaan:TeoridanPraktek.Medan: USU.Press.

Nugroho,Iwan.2012.PembangunanWilayah. : PerspektifEkonomi, Sosialdan Lingkungan, Jakarta : LP3ES.

Sirojuzilam.2011.ProblematikaWilayahKota .dan Daerah. Medan: USU Press.

Solekhan, M. 2014. Penyelenggaraan Pemerintahan Desa Berbasis Masyarakat. Malang: Setara Press.

Sugiyono. 2016. Metode Penelitian Kualitatif, Kuantitatif, $R \& D$. Bandung: Alfabeta.

Totok, Mardikanto dan Poerwoko, Soebianto. 2013. Pemberdayaan Masyarakat: Dalam Perspektif Kebijakan Publik. Bandung: Alfabeta.

Ratminto, Winarsih Septi Atik. 2015. Manajemen Pelayanan: Pengembangan Model Konseptual, Penerapan Citizen's Charter dan Standar Pelayanan Minimal. Pustaka Pelajar. Yogyakarta.

Sinambela, Lijan, Poltak. 2016. Reformasi Pelayanan Publik: Teori, Kebijakan dan Implementasi. Bumi Aksara. Jakarta.

Sumpeno, Wahjudin. 2011. Perencanaan Desa Terpadu. Banda Aceh: Read.

Tjiptono, Fandy. 2012. Service Management Mewujudkan Layanan Prima. Andi Offset. Yogyakarta.
Yeremias T. Keban, 2014. Enam Dimensi Strategis Administrasi Publik. Konsep Teori dan Isu. Edisi Ketiga. Gava Media. Yogyakarta. 